\title{
Reducing the Carcinogenic Impact of Pitch Processing
}

\author{
O. F. Sidorov ${ }^{a, b}$ \\ ${ }^{a}$ Yeltsin Ural Federal University, Yekaterinburg, Russia \\ ${ }^{b}$ OAO Vostochnyi Nauchno-Issledovatel'skii Uglekhimicheskii Institut, Yekaterinburg, Russia \\ e-mail: sidorole@mail.ru \\ Received November 15, 2012
}

\begin{abstract}
Diverse opinions exist regarding the properties of benz $[a]$ pyrene and other polycyclic aromatic hydrocarbons in coal pitch and their carcinogenic impact. Current concepts regarding chemical carcinogenesis and the development of occupational sickness are outlined. Information is presented relating to the reduction in the carcinogenic impact of coal pitch and its processing products. It is shown that the content of benz $[a]$ pyrene and other polycyclic aromatic hydrocarbons in coal pitch, its sublimates, and atmospheric emissions may be reduced by means of various additives. However, it is probably impossible to eliminate benz $[a]$ pyrene emission completely, since it is an unavoidable product of the high-temperature pyrolysis of organic materials.
\end{abstract}

DOI: $10.3103 / \mathrm{S} 1068364 \mathrm{X} 13020063$

About $80-90 \%$ of all human cancers may be attributed to chemical carcinogens such as polycyclic aromatic hydrocarbons. Some polycyclic aromatic hydrocarbons found in coal pitch and tar are supertoxic and have been assigned to the highest risk category, as confirmed by reliable epidemiological data.

At the beginning of the twentieth century, the carcinogenic impact of coal products on humans and other living creatures was experimentally demonstrated by Japanese scientists, probably for the first time [1]. Later, a compound with particularly severe carcinogenic impact was isolated from coal tar [2]. This compound is often referred to as 3,4-benzopyrene. It has been studied in hundreds of papers. Nevertheless, despite such prolonged study of the properties of 3,4-benzopyrene and its impact on the biosphere, some important questions remain unresolved.

\section{UNRESOLVED QUESTIONS}

(1) There is contradictory information regarding the relation between the chemical structure of benzopyrene and its designation. Benzopyrene exists and has been analytically determined in two isomeric forms, one of which (isomer I in Fig. 1) is a proven carcinogen.

By benzopyrene, we usually mean a compound with a link between the fifth benzene ring and the basic pyrene molecule. The many terms for the carcinogenic isomer may be traced to the IUPAC nomenclature, which determines the numbering of the carbon atoms in the pyrene molecule. Previously, the position $[a]$ (Fig. 1) was numbered 3,4, and the carcinogenic isomer was known as 3,4-benzopyrene; the position $[e]$ was numbered 1,2 and the other isomer was known as 1,2-benzopyrene. In recent years, according to IUPAC nomenclature, the numbering has changed, and now the carcinogenic isomer should be known as 1,2-benzopyrene, while the other is 4,5-benzopyrene [3]. In the present work, we call the carcinogenic isomer benz $[a]$ pyrene, the term commonly used outside of Russia.

(2) Benz $[a]$ pyrene is often regarded as the most common and most dangerous polycyclic aromatic hydrocarbon. Therefore, the carcinogenic impact of a particular process is assessed in terms of the benz $[a]$ pyrene emissions to the atmosphere. More than 60 carcinogenic polycyclic aromatic hydrocarbons are known. In recent years, the International Agency for Research on Cancer (IARC) has significantly expanded the roster of potentially toxic polycyclic aromatic hydrocarbons. Particular attention has been paid to dibenzopyrene, which, like benz $[a]$ pyrene, is formed whenever carbon materials undergo combustion or pyrolysis in insufficient air.

Such dibenzopyrene polymers as dibenz $[a, l]$ pyrene, dibenz $[a, e]$ pyrene, dibenz $[a, i]$ pyrene, and<smiles>c1ccc2c(c1)cc1ccc3cccc4ccc2c1c34</smiles>

I

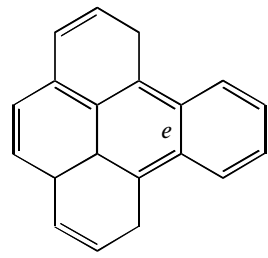

II
Fig. 1. Structural formulas of benzopyrene isomers. 
<smiles></smiles>

Dibenz $[a, l]$ pyrene<smiles>c1ccc2c(c1)cc1c3ccccc3c3cccc4ccc2c1c43</smiles>

Dibenz $[a, e]$ pyrene<smiles>c1ccc2c(c1)cc1ccc3cc4ccccc4c4ccc2c1c34</smiles>

Dibenz $[a, i]$ pyrene<smiles></smiles>

Dibenz $[a, h]$ pyrene
Fig. 2. Carcinogenic dibenzopyrenes.

dibenz $[a, h]$ pyrene (Fig. 2) are potentially more hazardous to humans than benz $[a]$ pyrene. Dibenz $[a, l]$ pyrene is the most dangerous human carcinogen - an order of magnitude more severe than benz $[a]$ pyrene, according to [4].

Some researchers have found a relation between the carcinogenic impact of polycyclic aromatic hydro-

Values of the equivalent toxicity factor (ETF) for polycyclic aromatic hydrocarbons

\begin{tabular}{r|l|c}
\hline No. & \multicolumn{1}{|c|}{$\begin{array}{c}\text { Polycyclic aromatic } \\
\text { hydrocarbon }\end{array}$} & ETF \\
\hline 1 & Naphthalene & 0.000 \\
2 & Acenaphthylene & 0.000 \\
3 & Acenaphthene & 0.000 \\
4 & Fluorene & 0.000 \\
5 & Phenanthrene & 0.000 \\
6 & Anthracene & 0.000 \\
7 & Fluoranthene & $\mathbf{0 . 0 3 4}$ \\
8 & Pyrene & 0.000 \\
9 & Benz[ $a]$ fluorene & 0.000 \\
10 & Benz[b]fluorene & 0.000 \\
$\mathbf{1 1}$ & Benz $[\boldsymbol{a}]$ anthracene & $\mathbf{0 . 0 3 3}$ \\
$\mathbf{1 2}$ & Chrysene & $\mathbf{0 . 2 6 0}$ \\
$\mathbf{1 3}$ & Benz $[\boldsymbol{b}]$ fluoranthene & $\mathbf{0 . 1 0 0}$ \\
$\mathbf{1 4}$ & Benz $[\boldsymbol{e}]$ pyrene & $\mathbf{0 . 0 5 0}$ \\
$\mathbf{1 5}$ & Benz $[\boldsymbol{a}]$ pyrene & $\mathbf{1 . 0 0 0}$ \\
$\mathbf{1 6}$ & Indene[1,2,3-c,d]pyrene & $\mathbf{0 . 1 0 0}$ \\
$\mathbf{1 7}$ & Dibenz $[\boldsymbol{a}, \boldsymbol{h}]$ anthracene & $\mathbf{1 . 4 0 0}$ \\
$\mathbf{1 8}$ & Benz $[\boldsymbol{g}, \boldsymbol{h}, \boldsymbol{i}]$ ]perylene & $\mathbf{1 . 0 0 0}$ \\
\hline
\end{tabular}

Note: Carcinogenic polycyclic aromatic hydrocarbons are shown in boldface.

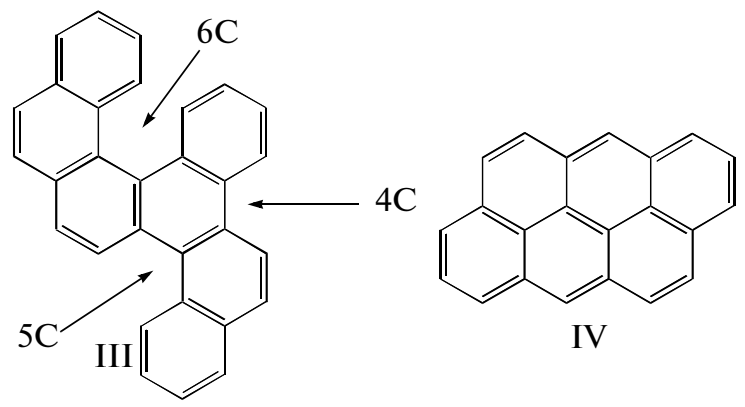

Fig. 3. Carcinogenic topological indicators of polycyclic aromatic hydrocarbons.

carbons and their chemical topology [5]. To that end, zones with high electron density that are associated with carcinogenic activity (segments 4C, 5C, and 6C in Fig. 3, III) have been identified in the structure of polycyclic aromatic hydrocarbons. However, this indicator is not universal, since there are materials with carcinogenic impact (for example, anthanthrene, Fig. 3, IV) that do not contain such zones.

The carcinogenic potential of polycyclic aromatic hydrocarbons is used to determine the quantitative risks for humans. The following principles are adopted in determining the carcinogenic potential.

A. The individual potential of a polycyclic aromatic hydrocarbon is determined from the equivalent toxicity factor (ETF) relative to benz $[a]$ pyrene, whose carcinogenicity is assumed to be one.

B. The total genotoxicity of polycyclic aromatic hydrocarbons is determined by addition.

By convention, benz $[a]$ pyrene is regarded as the indicator that carcinogenic polycyclic aromatic hydrocarbons are present.

In that case, the equivalent with respect to benz $[a]$ pyrene (EBP) for an individual polycyclic aromatic hydrocarbon will be the product of the equivalent toxicity factor and the concentration of the polycyclic aromatic hydrocarbon $(C$, wt \%)

$$
\mathrm{EBP}=\mathrm{ETFC} .
$$

In the literature, several approaches to estimating the equivalent toxicity factor have been proposed. For pitch, the most common approach is that recommended by United States' Environmental Protection Agency (EPA) [6]. That will be used in the present work; the corresponding ETF values are presented in the table.

In 2008, the Russian epidemiological standards expanded the list of carcinogenic factors to three hydrocarbons present in coal pitch or their thermal-destruction products - benz $[a]$ pyrene, benz $[a]$ anthracene, and dibenz $[a, h]$ anthracene. However, the health standards only consider one-benz $[a]$ pyrene. Therefore, the carcinogenic impact of atmospheric emissions from 
coke plants and other industrial enterprises is still evaluated on the basis solely of benz $[a]$ pyrene.

In most developed nations, the carcinogenic impact of high-temperature pyrolysis or combustion of hydrocarbon mixtures is based on the total toxicity of the polycyclic aromatic hydrocarbons formed. The standard documents determining the list of genotoxic polycyclic aromatic hydrocarbons are different in different countries and contain between 8 and 18 individual compounds. Regular research suggests that the number of hydrocarbons considered has recently been increasing. A list of 16 toxic polycyclic aromatic hydrocarbons has been published by the EPA. In Norway, this list has been expanded to 18 polycyclic aromatic hydrocarbons. In Canada and in the European Community, a list of eight polycyclic aromatic hydrocarbons is employed.

According to the EPA classification, seven out of the 16 priority polycyclic aromatic hydrocarbons that require atmospheric monitoring are carcinogenic for humans: benz $[a]$ anthracene, benz $[a]$ pyrene, benz $[b]$ fluoranthene, benz $[k]$ fluoranthene, chrysene, dibenz $[a, h]$ anthracene, and indeno[1,2,3-c, $d]$ pyrene [7]. The inclusion of polycyclic aromatic hydrocarbons that do not have carcinogenic and mutagenic activity may be explained by their predominance in the emissions from many technological processes and hence the possibility of establishing the source of pollution when they are found at specific locations. Thus, pyrene and fluoranthene are not carcinogenic but they are primary products in the pyrolysis of hydrocarbons.

Obviously, the carcinogenic impact of atmospheric emissions from processing plants will be much greater if determined from the sum of all genotoxic polycyclic aromatic hydrocarbons rather than from benz $[a]$ pyrene alone. Thus, experiments have shown that the carcinogenic impact of pitch sublimates according to the sum of toxic polycyclic aromatic hydrocarbons is $11-22$ times greater than the figure based on the benz[a]pyrene content [8].

In industrial atmospheric emissions, the benz $[a]$ pyrene concentration is not dominant. In Fig. 4, we compare the total carcinogenic potential of dibenzopyrenes (calculated from the equivalent toxicity factor) and the potential of benz $[a]$ pyrene determined in air samples from Stockholm [4].

It is evident from Fig. 4 that the carcinogenic potential of dibenzopyrene isomers is several times greater than that of benz $a$ ]pyrene [4].

Thus, it is wrong to assume that benz $[a]$ pyrene is dominant and exceptionally dangerous.

(3) It is an error to believe that carcinogenic polycyclic aromatic hydrocarbons derive only from human sources such as industrial enterprises (coke production, ferrous and nonferrous metallurgy), power plants (thermoelectric plants, boiler plants), and automobiles. Natural sources of carcinogenic polycyclic aro-

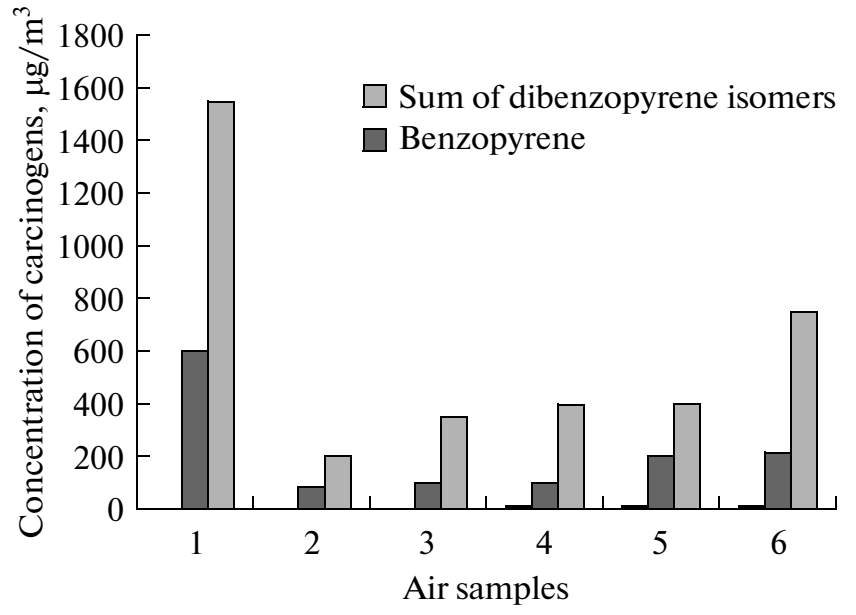

Fig. 4. Carcinogenic potential of the sum of dibenzopyrene isomers and of benz $[a]$ pyrene alone in urban air samples.

matic hydrocarbons include forest fires, peat-bog combustion, and volcanic eruptions.

Benz $[a]$ pyrene and other carcinogenic polycyclic aromatic hydrocarbons are always present in the environment. The possibility of synthesis of polycyclic aromatic hydrocarbons by various microorganisms and plants has been proven experimentally. By this means, benz $[a]$ pyrene is released in the biosphere at rates up to $1000 \mathrm{t} / \mathrm{yr}$ [9]. Since the green mass of plants always contains benz $[a]$ pyrene, whose concentration is no lower than $1 \mu \mathrm{g} / \mathrm{kg}$, as a rule, all natural fuels (oil, coal, peat, shale) will contain benz $[a]$ pyrene and other carcinogenic polycyclic aromatic hydrocarbons. For that reason, we cannot ascribe the presence of benz $[a]$ pyrene in the environment solely to industrial and other human sources.

Certainly, the quantity of benz $[a]$ pyrene synthesized by biogenic sources is not comparable with the quantity synthesized by anthropogenic or natural pyrolytic processes. According to the SanPiN 2.3.2.1078-01 public-health standards, the limiting permissible background content of benz $[a]$ pyrene in the air in residential areas is $1 \times 10^{-3} \mu \mathrm{g} / \mathrm{m}^{3}$, which is approximately its natural concentration. Close to pitch-processing facilities (pitch-coke plants, electrode plants, etc.), by contrast, the analytically determined benz $[a]$ pyrene concentration is thousands of times greater.

(4) Divergent opinions exist regarding the causeand-effect sequence between exposure to benz $[a]$ pyrene and the development of cancer. There is a common assumption that cancer deaths are due to workplace exposures to benz $[a]$ pyrene. However, we know that, when working with chemically pure benz $[a]$ pyrene, no cancers are seen [10]. Current research shows that the action of mutagenic chemicals on the human organism (the carcinogenic process) passes through several stages before a tumor is formed 
$[5,10,11]$. As a rule, three such stages are identified: initiation, promotion, and progression.

Initiation involves the direct action of the carcinogen on cells, triggering their transformation. The initiation stage includes fast and practically irreversible damage to the genetic material of the cells, preparing them for subsequent neoplastic development. The damaged cells are said to be initiated. Replication of the genetic material is required so that the mutations are fixed. According to current concepts, the initiated cell may remain in a dormant state for a long time, until some other factor provokes cell division, cloning, and tumor formation.

Promotion is the process in which the initiated cell completes neoplastic transformation. The materials responsible for promotion are not carcinogens, strictly speaking, but their action is necessary for tumor development. Promoters may include hormones, pharmaceuticals, or products of plant metabolism that interact with the cell membrane and receptor structures of the initiated cell's nucleus or protoplasm and provoke cell division. Potential promoters include nutritional fats, tobacco smoke, asbestos, halogenated hydrocarbons, and alcohol. Some carcinogens are both initiators and promoters (complete carcinogens).

Progression is the process in which a benign tumor is converted into a malignant tumor. It involves further transformation of the cells' genetic material.

The carcinogenic polycyclic aromatic hydrocarbons found in pitch and coal tar are genotoxic agents. They give rise to delayed effects that are generally due to the cumulative action of small doses. This group of materials has a distinctive action on the molecules that are the carriers of inheritance. Besides the direct action of carcinogens on the DNA molecules, they may also activate the formation of free radicals in the cells of the organism. The importance of the latter mechanism in carcinogenesis is indirectly demonstrated by the experimental finding that antioxidants are able to suppress chemical carcinogenesis.

Thus, in the broad sense of the term, carcinogens are both initiators and promoters of tumor growth and hence the carcinogenic action of chemicals is an extremely complex process, which may take many forms. Consequently, we cannot regard carcinogenic activity and carcinogenic hazard as synonyms. That explains many of the inconsistent results relating the cancer mortality rates of a population to the concentration of carcinogens in the vicinity. The data regarding cancer mortality associated with professional exposure are also contradictory. According to specialists in the United States, they may account for between $5 \%$ and $20 \%$ of all cancer deaths in the country.

(5) There is significant discrepancy in the results for the benz $[a]$ pyrene concentration in pitch that are used to assess its carcinogenic impact. Since there are no physicochemical methods for the direct determination of the content of benz $[a]$ pyrene and other polycyclic aromatic hydrocarbons in pitch, the analysis is based on pitch fractions dissolved in benzene, toluene, carbon disulfide, or another solvent. These fractions contain $\sim 80 \%$ of the pitch hydrocarbons and practically all of the potentially hazardous polycyclic aromatic hydrocarbons. Therefore, certain subjective errors appear even in preparing the samples for analysis. However, the greatest discrepancy in the results is observed when using different analytical methods.

The benz $[a]$ pyrene concentration in coal pitch determined by spectral-fluorescent methods (2.3$5.1 \%)$ or by direct paper chromatography $(2.6-3.9 \%)$ are markedly higher than those found by capillary gas chromatography or efficient liquid chromatography $(0.8-1.2 \%)$, as shown in [12]. Spectral-fluorescent methods are extremely sensitive, which is important in determining microquantities of polycyclic aromatic hydrocarbons. However, when determining larger quantities of polycyclic aromatic hydrocarbons, their fluorescence spectra are very intense but poorly resolved, and the possibility of superposition of the spectra cannot be ruled out. Therefore, the benz $[a]$ pyrene content in coal pitch determined by fluorescent spectroscopy without preliminary multistage purification will probably be overestimated.

Note that no analytical method permits quantitative estimation of the carcinogenic hazard posed by a particular pitch, since synergetic effects in a mixture of hydrocarbons cannot be taken into account. That problem can only be solved by medical experiments on animals, which offer conclusive evidence of blastomogenic hazard (that is, the risk of creating mutagenic cell neoplasm).

In these experiments, the assessment of their carcinogenic activity assumes $100 \%$ involvement of the material being investigated. However, experiments on mice have shown that radical differences in the carcinogenic potential of pitch samples exist in their $\gamma$ fraction [12]. The toluene-insoluble $\alpha$ fraction of the pitch samples has no carcinogenic activity. On that basis, we may show that the carcinogenic hazard is $32 \%$ greater for high-temperature pitch of rank $\mathrm{C}$ (according to State Standard GOST 10200-83) than for mediumtemperature pitch of rank B.

In the carbonization of coal pitch of pitch-coke composites to $900^{\circ} \mathrm{C}$, dibenz $[a, l]$ pyrene is released at temperatures above $\sim 400^{\circ} \mathrm{C}$. Some of the initial benz $[a]$ pyrene in the coal pitch evaporates on carbonization and collects in the pitch tar, while the rest is converted to higher-molecular hydrocarbons and ultimately to coke [8]. An important and often ignored feature of pitch carbonization is that benz $[a]$ pyrene and other polycyclic aromatic hydrocarbons are synthesized in the gas phase above $750^{\circ} \mathrm{C}$.

Balance calculations show that, in the carbonization of coal pitch, about $44 \%$ of the initial benz $[a]$ pyrene evaporates and passes to the coal tar, while $56 \%$ is converted to coke. The evaporation of 
benz $[a]$ pyrene and other carcinogenic polycyclic aromatic hydrocarbons in the pitch sublimates is greatest at at $390-550^{\circ} \mathrm{C}$. However, in most technological processes, those polycyclic aromatic hydrocarbons are easily trapped by cooling and condensation. The greatest environmental hazard is posed by benz $[a]$ pyrene and other carcinogenic polycyclic aromatic hydrocarbons synthesized in the pyrolysis of simple unsaturated hydrocarbons at $750-800^{\circ} \mathrm{C}$.

Those polycyclic aromatic hydrocarbons are present in the exhaust gases - that is, after collection of the pitch tar. The benz $[a]$ pyrene content in the exhaust gases is $450-500 \mathrm{mg} / \mathrm{m}^{3}$ and does not depend on the benz[a]pyrene content in the initial pitch [8]. Accordingly, the exhaust gases must be regarded as determining the carcinogenic impact of pitch processing, since they cannot be neutralized by the usual sorptional purification and, without effective thermocatalytic treatment, they will be very hazardous atmospheric pollutants.

(6) There are doubts regarding the view that the carcinogenic impact from the carbonization of coal pitch is greater than that for the carbonization of petroleum pitch. Experiments have shown that adding petroleum bitumen to coal pitch prior to carbonization actually increases the benz $[a]$ pyrene content in the exhaust gases at $800^{\circ} \mathrm{C}$, rather than reducing it [13]. The finding that the benz[a]pyrene content in the exhaust gases is independent of its content in the initial pitch proves helpful here [8]. In fact, with effective trapping of pitch tar, the coking of coal pitch, petroleum pitch, or their mixture will have basically the same carcinogenic impact, on account of the approximately equal benz $[a]$ pyrene content in the exhaust gases at $800^{\circ} \mathrm{C}$.

\section{REDUCING THE CARCINOGENIC IMPACT OF PITCH PROCESSING}

Only a few methods of diminishing the carcinogenic impact of coal pitch and their gaseous processing products are mentioned in the literature [14, 15]. Physical methods include the treatment of coal-pitch by ultrasound $(600 \mathrm{kHz} / \mathrm{s})$ or by high-frequency currents (at ultrashort wavelengths) [16]. A method of reducing the benz $[a]$ pyrene content in atmospheric emissions by means of UV radiation with a mean light-flux density of gas irradiation in the range $0.001-0.300 \mathrm{~J} / \mathrm{cm}^{2}$ has been patented [17]. Hightemperature pitch $\left(T_{\mathrm{s}}=156-196^{\circ} \mathrm{C}\right.$ according to Mettler) with $0.035 \%$ benz $[a]$ pyrene may be produced from medium-temperature pitch $\left(T_{\mathrm{s}}=89^{\circ} \mathrm{C}\right.$ according to Mettler) containing $1.1 \%$ benz $[a]$ pyrene by the method in [18]. To this end, the medium-temperature pitch is distilled in a thin-layer evaporator at $300^{\circ} \mathrm{C}$ in vacuum (100 Pa) for $5 \mathrm{~min}$.

Chemical methods permit effective lowering of the benz $[a]$ pyrene content (with elimination of the carci- nogenic impact) by passing hydrocarbon mixtures through sulfuric acid, with subsequent buffering $[19,20]$. However, in most known chemical methods, the pitch loses its technological properties and can no longer be used as an electrode binder. Such methods include acetoxylation of pitch by lead tetraacetate; treatment with strong oxidants (hydrogen peroxides, potassium bichromate [21]) or alkylating agents (56 carbon atoms) in the presence of Friedel-Crafts catalysts [22, 23]; and catalytic hydrogenation.

The benz $[a]$ pyrene content in coal pitch is reduced, without loss of its technological properties, by adding $3-5 \%$ adsorbents (activated carbon) with mean pore radius $2.6-3.7 \mathrm{~nm}$ and subsequent holding at 175$290^{\circ} \mathrm{C}$ [24] or by heat treatment in the presence of titanium dioxide [25]. The benz[a]pyrene content is reduced by carbonization of pitch-coke composites in the anode mass using hybrid electric binders: mixtures of coal pitch with petroleum pitch [26, 27], shale tar, or heavy pyrolytic tar [28, 29]. Carbonization of coal pitch in the presence of $3 d$-transition metals (iron, nickel, etc.) reduces the benz $[a]$ pyrene content and completely eliminates its emission [30, 31].

Diverse opinions may be noted regarding the influence of thermooxidation on the carcinogenic impact of coal-tar pitch. Nevertheless, most researchers have experimentally confirmed that the thermooxidation of coal-tar pitch by air, oxygen, or ozone reduces its carcinogenic potential. The disagreement concerns quantitative estimates of the decrease in carcinogenic impact as a function of the thermooxidation conditions.

The most optimistic Russian researchers assume that the benz $[a]$ pyrene content may be reduced by a factor of 10-15 in the thermooxidation of coal pitch with small atmospheric additions of ozone [32]. Foreign researchers obtained a similar result in the thermooxidation of the anthracene fraction of pitch by air. That fraction has a benz $[a]$ pyrene content an order of magnitude smaller than for pitch obtained from the same anthracene fraction by thermal preparation [33].

The effectiveness of thermooxidation depends on the temperature of the process. In thermooxidation by air at $250-300^{\circ} \mathrm{C}$, the carcinogenic activity is reduced $[32,34]$. At $370-390^{\circ} \mathrm{C}$, by contrast, the carcinogenic activity is increased very significantly. Even the temperature rise from 340 to $380^{\circ} \mathrm{C}$ increases the benz $[a]$ pyrene content by more than $1 \%$ [32].

The influence of the temperature is clearly evident in the distillation of coal tar, when the elevated tar temperature in a tubular furnace $\left(\sim 400 \pm 10^{\circ} \mathrm{C}\right)$ and the prolonged holding of the pitch in the second-stage evaporator result in nonadditive increase in the benz $[a]$ pyrene accumulation in the final pitch $[32,35]$. Industrial experiments show that, on heating tar to $355^{\circ} \mathrm{C}$, there is practically no further benz $[a]$ pyrene formation; its content in the pitch correlates with the pitch yield from tar [32]. 
The synthesis of benz $[a]$ pyrene at thermooxidation temperatures of $370-390^{\circ} \mathrm{C}$ is possible in liquid or vapor-gas phase by the condensation of low-molecular (two- or three-ring) polycyclic aromatic hydrocarbons with radicals formed in the reductive and thermal destruction of high-molecular polycyclic aromatic hydrocarbons present in the $\beta$ and $\alpha$ fractions [34].

Therefore, one method of reducing the benz $[a]$ pyrene content in the pitch is to remove the low-molecular polycyclic aromatic hydrocarbons from the high-temperature zone before their conversion to benz $[a]$ pyrene. That involves periodic distillation, when the low-molecular polycyclic aromatic hydrocarbons gradually evaporate before the temperature of possible benz[a]pyrene synthesis is attained, and consequently its content in the pitch is less than in continuous distillation.

For that reason, the benz $[a]$ pyrene content in the pitch is 2-2.5 times less after double distillation of tar $\left(330^{\circ} \mathrm{C}\right.$ in the first stage and $390^{\circ} \mathrm{C}$ in the second) than after single-stage distillation [34]. Reduced benz $[a]$ pyrene content is also observed in vacuum-distilled pitch when the tar is heated at $370-380^{\circ} \mathrm{C}$ or less.

Experiments have confirmed that the quantity of toxic pitch sublimates and their content of carcinogenic polycyclic aromatic hydrocarbons may be reduced by introducing additives to the pitch [13]. Some additives are able to reduce the benz $[a]$ pyrene content in the atmospheric emissions. However, complete suppression of gas-phase benz $[a]$ pyrene synthesis at $750-800^{\circ} \mathrm{C}$ or more has proven impossible. We may suppose that, since the unsaturated hydrocarbons required for benz $[a]$ pyrene synthesis are present in the gas phase during the pyrolysis of practically any hydrocarbon material (coal pitch, petroleum pitch, etc.), benz $[a]$ pyrene in the exhaust gases is an unavoidable product of its high-temperature processing.

\section{REFERENCES}

1. Yamagiwa, K. and Ichigawa, K., J. Med. Coll. Imperial Univ. Tokyo, 1916, no. 15, no. 2, p. 295.

2. Cook, J., Hieger, I., Kennawey, E.I., and Mayneord, W.V., Proc. Roy. Soc. B, vol. 111, p. 455, 1932.

3. Khimicheskaya entsiklopediya (Chemical Encyclopedia), Moscow: Sov. Entsikl., 1988, vol. 1.

4. Bergland, C. and Westerholm, R., Identification and Determination of Highly Carcinogenic Dibenzopyrene Isomers in Air Particulate Samples from a Street Canyon, a Rooftop, and a Subway Station in Stockholm, Environ. Sci. Technol., 2007, vol. 41, pp. 731-737.

5. Carcinogenic and Other Polycyclic Aromatic Hydrocarbons: Environmental and Human Health Effects, Canadian Soil Quality Guidelines, 2008.

6. Wiles, F., Friar, S., and Barry, I., Application of Risk Assessment to Point Sources of Polycyclic Aromatic Hydrocarbons, Fifth Conference on Toxic Substances, Montreal, Canada, 1992.
7. US Environmental Protection Agency (EPA), Proposed Guidelines for Carcinogenic Risk Assessment, Fed. Register, 1996, vol. 61, pp. 17059-189011.

8. Sidorov, O.F., Dynamics of Carcinogenic Hydrocarbon Deposition in the Carbonization of Coal Pitches and Their Composites, Koks Khim., 2012, no. 12, pp. 28-34.

9. Khudolei, V.V. and Mizgirev, I.V., Ekologicheski opasnye factory (Environmental Risk Factors), St Petersburg: AOZT UPFF, 1996.

10. Kantserogenez (Carcinogenesis), Zaridze, D.G., Ed., Moscow: Meditsina, 2004.

11. Kutsenko, S.A., Osnovy toksikologii (Principles of Toxicology), St. Petersburg, 2002.

12. Sidorov, O.F., Environmental Problems with Coal Pitches, Sb. dokl. mezhdunar. konferentsii Sovremennoe sostoyanie i perspektivy razvitiya elektrodnoi produktsii, konstruktsionnykh i kompozitsionnykh materialov (Proceedings of an International Conference on the Development of Electrode Production, Building Materials, and Composites), Chelyabinsk: Entsiklopediya, 2010, pp. 86-96.

13. Sidorov, O.F., Carbonization of Coal Pitch in the Presence of Additives, Koks Khim., 2013, no. 1, pp. 28-35.

14. Slyshkina, T.V. and Sukhorukov, V.I., Developing Methods of Reducing the Carcinogenic Impact of Coal-Tar Binders, Koks Khim., 1998, no. 6, pp. 26-32.

15. Donetskaya, O.A., Eksperimental'nye obosnovaniya dekantserogenizatsii kantserogennykh produktov promyshlennosti (Experimental Confirmation of Reduction in the Carcinogenic Impact of Industrial Carcinogens), Leningrad: Meditsina, 1971.

16. Skripchenko, G.B., Sekrigru, V.I., Larina, N.N., et al., Irradiation of Heavy Petroleum and Coal Products, Khim. Tverd. Topl., 1986, no. 4, pp. 55-59.

17. Kashnikov, G.N., Krasnen'kov, V.M., and Tarabukin, A.A., RF Patent 2133636, 1999.

18. Mackerer, C.R. et al., US Patent 6010617, 2000.

19. Sidorov, O.F. and Machalov, V.V., Inventor's Certificate 695222.

20. Sidorov, O.F. and Machalov, V.V., Some Properties of VOKS and VOKSAN Coal Binders, Koks Khim., no. 7, pp. 33-35.

21. Donetskaya, O.L., Eksperimental'nye obosnovaniya dekantserogenizatsii kantserogennykh produktov promyshlennosti (Experimental Confirmation of Reduction in the Carcinogenic Impact of Industrial Carcinogens), Leningrad: Meditsina, 1971.

22. Blackburn, G.R., Roy, T.A., and Mackerer, C.R., US Patent 5488 193, 1996.

23. Zieliñski, J., Osowiecka, R., Liszyñska, B., et al., Benz[a]pyrene in Coal-Tar Pitch: Chemical Conversion in Situ by Alkylation, Fuel, 1996, vol. 75, pp. 1548-1549.

24. Anshits, A.G., Nizov, V.A., Suzdorf, A.R., et al., RF Patent 2088694, 1997.

25. Kubica, K., Topolnicka, T., and Kordas, T., The Influence of Titanium Oxide on PAHs Behavior during the Process of Coal Pitch Thermolysis, Proceedings of the Carbon Conference, 2005.

26. Ragozin, L.V., Efimov, A.A., Bakhtin, A.A., et al, RF Patent 2196192, 2003. 
27. Perez, M., Granda, M., Santamaria, R., et al., Carbon Anodes from Coal-Tar Pitch: Petroleum Pitch Blends, Proceedings of the Carbon Conference, Oviedo, Spain, 2003.

28. Glushkevich, M.A., Lazarev, D.G., Tepikin, S.V., et al., Compounding of Binder for Anode Mass on the Basis of B Pitch and Heavy Tar from Pyrolysis, Mezhd. nauch.-tekhn. konf. (International Technical Conference), Yekaterinburg: UGTU-UPI, 2008, pp. 110113.

29. Lebedeva, I.P., Doshlov, O.I., Lazarev, D.G., et al., Sovremennye resursosberegayushchie tekhnologii $v$ metallurgicheskom proizvodstve (Modern Resource-Conserving Technologies in Metallurgical Production).

30. Barnakov, Ch.N. et al., Method of Removing Benzopyrene in the Production of Anode Carbon, Khim. Khim. Tekhnol., 2010, vol. 53, no. 10, p. 115.
31. Barnakov, Ch.N., Seit-Abdaeva, S.K., Kozlov, A.P., et al., RF Patent 2370837; Byull. Izobret., 2009, no. 29.

32. Sukhorukova, E.A., Kharlampovich, G.D., Slyshkina, T.V., et al., Possibility of Reducing the 3,4-Benzopyrene Content in Coal Pitch, Koks Khim., 1984, no. 7, pp. 36-38.

33. Alvarez, P., Granda, M., Sutil, J., et al., Preparation of Low-Toxicity Pitches by Thermal Oxidative Condensation of Anthracene Oil, Env. Sci. Technol., 2009, vol. 43(21), pp. 8126-8132.

34. Branin, O.B., Production of Coal Pitch with Reduced Benz $[a]$ pyrene Content, Cand. Sci. Dissertation, Kharkov, 1991.

35. Slyshkina, T.V., Kuz'minykh, A.I., and Sukhorukov, V.I., Technological Properties and Carcinogenicity of Coaland Petroleum-Based Binders, Koks Khim., 1998, no. 3, pp. 26-31. 